Arch Virol (1988) 103: 35-45

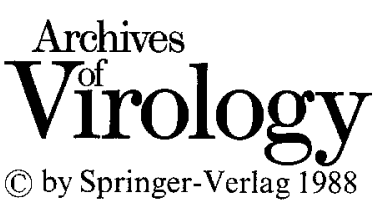

\title{
Structural proteins of bovine coronavirus strain L 9: effects of the host cell and trypsin treatment
}

\author{
K. St. Cyr-Coats, J. Storz, K.A. Hussain, and K.L. Schnorr \\ Department of Veterinary Microbiology and Parasitology, School of Veterinary Medicine, \\ Louisiana State University, Baton Rouge, Louisiana, U.S.A.
}

Accepted August 12, 1988

\begin{abstract}
Summary. The polypeptide profile of the cell-adapted strain of bovine coronavirus (Mebus BCV-L9) is remarkably affected by the host cell and trypsin. We compared the structural proteins of virus purified from different cell lines and found cell-dependent differences in the virus structure. $\mathrm{BCV}$ was purified from four clones of human rectal tumour cells (HRT-18): 3F3, D 2, 3 E 3, and 4 B 3. The structural profiles of $\mathrm{BCV}$ propagated in clones $3 \mathrm{E} 3$ and $3 \mathrm{~F} 3$ were identical, consisting of proteins with molecular weights of $185,160,140,125,110$, $100,52,46,37,31-34$, and $26-28$ kilodaltons (kd). BCV purified from clone D2 lacked the $100 \mathrm{kd}$ species, and clone $4 \mathrm{~B} 3$ yielded virus lacking the $46 \mathrm{kd}$ protein. We compared the structures of $\mathrm{BCV}$ propagated in HRT-18 cells $[\mathrm{BCV}(\mathrm{HRT}-18)]$ and virus raised in bovine fetal spleen cells [BCV(D 2 BFS $)]$. The concentration of the $185 \mathrm{kd}$ protein was higher in BCV (D 2BFS), and it also contained a $200 \mathrm{kd}$ species. Protein profiles of in vitro trypsin treated and untreated BCV(HRT-18) differed only under reducing conditions, suggesting that trypsin cleavage sites are located within disulfide-linked regions of affected proteins. Propagation of BCV in D 2 BFS cells in the presence of trypsin resulted in cleavage of the $185 \mathrm{kd}$ protein and a concommitant increase of the $100 \mathrm{kd}$ protein. Activation of the fusion function probably depends on this cleavage process because fusion of $\mathrm{BCV}$-infected $\mathrm{D} 2 \mathrm{BFS}$ cells is trypsin dependent.
\end{abstract}

\section{Introduction}

Proteolytic cleavage of inactive precursor polypeptides of assembled virions into an active form is necessary for inducing the infectivity of a number of viruses. Notably, orthomyxoviruses and paramyxoviruses require cleavage of envelope proteins for the viruses to become infectious. Processing of the viral proteins is accomplished either by cellular proteases or by exogenous proteases such as trypsin $[2,3,7,9,10,11,18,19]$. Such findings are emerging for 
coronaviruses as well. Frana et al. [6] found that processing of the $180 \mathrm{kd}$ glycoprotein of mouse hepatitis virus strain A 59 (MHV-A 59) was host celldependent and affected the functional capacity of the virus. Those cells which fully cleaved the $180 \mathrm{kd}$ protein to its $90 \mathrm{kd}$ subunits activated rapid cell fusion. Cells which cleaved the protein incompletely required trypsin to activate rapid cell fusion.

Trypsin enhances the replication and cytopathic expression of bovine coronaviruses. We demonstrated trypsin-dependent cell fusion of bovine fetal spleen cells infected with BCV-L9 [20]. Storz and coworkers [21] reported enhanced cell fusion of BCV-L9 infected bovine fetal brain and bovine fetal thyroid cells in the presence of trypsin. The protein responsible for cell fusion has not been determined. BCV virions with shortened surface projections were produced in trypsin-treated bovine fetal thyroid cell cultures [21]. Williams [31] detected two phenotypes of virus when BCV-L9 was purified from human rectal tumour-18 (HRT-18) cells by isopycnic cetrifugation in sucrose or $\mathrm{CsCl}$ gradients. The dense and light forms of the virus had densities of 1.255 and $1.233 \mathrm{~g} / \mathrm{cm}^{3}$, respectively. The two virus forms had distinct polypeptide profiles, and the light form was converted to the dense form by in vitro trypsin treatment.

One objective of this study was to assess putative cell-dependent differences in the protein composition of BCV-L9. The virus was propagated in HRT-18 parent cells, four different HRT-18 clones [St. Cyr-Coats et al., submitted], and bovine fetal spleen cells (D 2BFS). These cells display different cythopathic effects when infected with the virus. A second objective was to compare the protein profiles in vitro trypsin-treated or untreated BCV-L 9 propagated in HRT-18 and D2BFS cells. The profiles were examined under reducing and non-reducing conditions to reveal the effect of the enzyme on the viral polypeptides. D 2BFS cells infected with BCV require trypsin to activate cell fusion, which provided conditions to identify the viral protein(s) responsible for cell fusion.

\section{Materials and methods}

\section{Cells and virus}

The human adenocarcinoma cell line (HRT-18) and four HRT-18 clones, 3F3, D 2, $3 \mathrm{E} 3$, and $4 \mathrm{~B} 3$, established by limiting dilution, were grown in $850 \mathrm{~cm}^{2}$ Corning roller bottles or in $150 \mathrm{~cm}^{2}$ flasks. When seeded in roller bottles, $25 \mathrm{mM}$ HEPES and $12 \mathrm{mM}$ $\mathrm{NaHCO}_{3}$ were supplemented to stabilize $\mathrm{pH}$ in Dulbecco's Modified Minimum Essential Medium (DMEM) (Gibco). After 1 day incubation at $37^{\circ} \mathrm{C}$, this medium was replaced with DMEM containing $44 \mathrm{mM} \mathrm{NaHCO}$, penicillin (100 units/ml), streptomycin $(100 \mu \mathrm{g} / \mathrm{ml})$, and $5 \%$ fetal calf serum. D2BFS cells are a heterogenous subpopulation derived from bovine fetal spleen cells which overcame precrisis to multiply past the 30th passage. These cells were grown in Eagles Minimum Essential Medium (MEM) containing $25 \mathrm{mM}$ HEPES, penicillin and streptomycin, and $10 \%$ fetal calf serum.

BCV-L 9 is a bovine coronavirus strain adapted to cell culture by Mebus et al. [15]. This virus was plaque purified twice before use in these investigations. 
Virus growth and purification from $H R T-18$ cells

HRT-18 cells were infected with BCV-L9 at an MOI of 0.01-0.1 PFU/cell. Following adsorption for $1 \mathrm{~h}$ at $37^{\circ} \mathrm{C}$, excess inoculum was removed and cells were washed three times with Dulbecco's PBS. Medium was added, and cells were incubated at $37^{\circ} \mathrm{C}$. When CPE affected approximately $80 \%$ of the monolayer, cells were frozen at $-70^{\circ} \mathrm{C}$. Bottles were thawed; the infected material was pooled into $250 \mathrm{ml}$ centrifuge bottles, sonicated, and refrozen.

Virus was purified from thawed cell lysate by isopycnic centrifugation in linear sucrose gradients according to the procedure described by Wege et al. [22]. Gradient fractions were collected by puncturing the bottom of the centrifuge tubes. Viruscontaining fractions were identified by hemagglutinating activity (HA). Fractions containing the highest HA titers were pooled and concentrated by sedimentation through a $5 \mathrm{ml} 20 \%$ sucrose cushion for $2 \mathrm{~h}$ at $90000 \times \mathrm{g}$. Virus was resuspended in TNE buffer $(0.01 \mathrm{M}$ tris-HCL, $0.01 \mathrm{M} \mathrm{NaCl}, 0.001 \mathrm{M}$ EDTA), $\mathrm{pH}$ 7.4. This virus preparation was considered partially purified. For further purification the virus suspension was layered onto a preformed CsCl-TNE gradient $\left(1.0606-1.2886 \mathrm{~g} / \mathrm{cm}^{3}\right)$ and centrifuged at $55,000 \times \mathbf{g}$ for $20 \mathrm{~h}$. Bands were collected as described above, concentrated, and resuspended in TNE buffer.

\section{Propagation and concentration of virus from D2BFS cells}

To minimize loss of virus, BCV-L 9 was directly concentrated from D2BFS cells, which produce low yields of virus in the absence of trypsin. D2BFS cells in $150 \mathrm{~cm}^{2}$ flasks were infected with BCV-L 9 at an MOI of approximately $0.1 \mathrm{PFU} /$ cell. After absorption, cells were washed 3 times to remove unadsorbed virus. MEM was added to one set of flasks, and MEM with $5 \mu \mathrm{g} / \mathrm{ml}$ trypsin (Difco; $1: 250$ ) was added to the other set. Flasks were incubated at $37^{\circ} \mathrm{C}$ for 3 days, then frozen at $-70^{\circ} \mathrm{C}$, thawed, and the cell lysate was pooled. Fluid was clarified at $10,000 \times \mathrm{g}$ for $20 \mathrm{~min}$ to remove cell material, then concentrated as described.

\section{Preparation of uninfected cell antigen for Western blots}

Washed cells in $150 \mathrm{~cm}^{2}$ flasks were frozen at $-70^{\circ} \mathrm{C}$, thawed, and cell lysate was collected in centrifuge tubes. Cell lysate was sonicated for $1 \mathrm{~min}$, then the suspension was centrifuged at $1,000 \times \mathbf{g}$ for $15 \mathrm{~min}$ to settle nuclei. The supernatant was centrifuged at $90,000 \times \mathrm{g}$ for $2 \mathrm{~h}$, and the pellet was resuspended in TNE buffer.

\section{In vitro trypsin treatment}

Aliquots of partially purified virus preparations were treated with $1 \mu \mathrm{g} / \mathrm{ml}$ trypsin (Sigma, TPCK treated) in Dulbecco's PBS at $37^{\circ} \mathrm{C}$ for $30 \mathrm{~min}$. The action of trypsin was stopped by the addition of $1 \mu \mathrm{g} / \mathrm{ml}$ soybean trypsin inhibitor (Sigma) and incubation at $4^{\circ} \mathrm{C}$ for $30 \mathrm{~min}$. The virus suspension was centrifuged through a $2 \mathrm{ml} 20 \%$ sucroseTNE cushion at $90,000 \times \mathbf{g}$ for $2 \mathrm{~h}$. Pellets were resuspended to original volume in TNE buffer.

\section{Polyacrylamide gel electrophoresis}

Sodium dodecyl sulfate - polyacrylamide gel electrophoresis (SDS-PAGE) of virus samples was done using the Laemmli buffer system [14] in the presence or absence of the reducing agent, $\beta$-mercaptoethanol. Gels containing 10 or $12 \%$ bis-acrylamide were prepared in $1 \mathrm{~mm}$ thickness, and run at a constant power of 4 watts/gel (approximately 
$25 \mathrm{~mA} / \mathrm{gel}$ ) for 3-4h. BioRad low and high molecular weight standards ranging from 14,400 to 200,000 daltons were used. Proteins were visualized using the BioRad silver stain kit developed according to the procedure of Merrill et al. [16] or by Western blotting.

\section{Western blot procedures}

Western blots were done according to a modification of the procedure of Burnette [1]. Briefly, proteins were separated by SDS-PAGE and transferred to nitrocellulose membranes using Tris-glycine transfer buffer $(20 \mathrm{mM}$ Tris base, $150 \mathrm{mM}$ glycine), $\mathrm{pH} 8.3$. Electrophoretic transfer was carried out for 18 to $20 \mathrm{~h}$ at 35 volts at 10 to $15^{\circ} \mathrm{C}$. Transferred proteins were stained with Ponceau S [17], and molecular weight markers were cut off and saved for use in determining molecular weights of viral proteins. Transferred viral proteins were localized by incubating bovine anticoronavirus serum with blotted nitrocellulose membranes for 16 to $18 \mathrm{~h}$. Goat antibovine $\operatorname{IgG}(\mathrm{H}+\mathrm{L}$ chain) peroxidase conjugate (Kirkegaard and Perry Laboratories) was used. Membranes were developed by reacting with substrate consisting of $15 \mathrm{mg}$ 4-chloro 1naphthol dissolved in $5 \mathrm{ml}$ methanol, followed by addition of $25 \mathrm{ml} 0.05 \mathrm{M}$ Tris $\mathrm{pH}$ 6.8 , and $12 \mu 1 \mathrm{H}_{2} \mathrm{O}_{2}$.

\section{Results}

Comparison under reducing and non-reducing conditions of the polypeptide structure of $B C V-L 9$ propagated in different cells

The polypeptide profiles of BCV-L 9, partially purified from HRT-18 clones D2, 3E3, 3F3, and 4B3 were analyzed by Western blotting (Fig. 1). We observed cell-dependent differences in virus structure. Under non-reducing conditions viral proteins of $185,160,140,125,110,100,52,46,37,31-34$, and $26-28 \mathrm{kd}$ were detected from clones $3 \mathrm{E} 3$ and $3 F 3$. However, the $46 \mathrm{kd}$ protein was absent in BCV purified from clone $4 \mathrm{~B} 3$. Doublet bands of 110 and $100 \mathrm{kd}$ were found with $\mathrm{BCV}$ obtained from clones $3 \mathrm{~F} 3,3 \mathrm{E} 3$, and $4 \mathrm{~B} 3$, but only a single $100 \mathrm{kd}$ band was present in virus from clone D2. To illustrate this finding, the profiles of BCV propagated in clones D2 and 3F3 are compared in Fig. 2. The viral structural proteins thus follow the characteristic pattern of high, intermediate and low molecular weight of coronaviruses.

BCV propagated in HRT-18 cells [BCV(HRT-18)] and D2BFS cells $[\mathrm{BCV}(\mathrm{D} 2 \mathrm{BFS})]$ shared common proteins of $185,160,140,100,52,37$, and 31-34 kd (Fig. 3). Notable structural differences included the following: A $>200 \mathrm{kd}$ protein was found in D2BFS-produced virus, but not in virus obtained from HRT-18 cells. The $185 \mathrm{kd}$ protein was present a high concentration in BCV(D2BFS), but in proportion to the other proteins comprising the profile, it was present at low concentration in BCV(HRT-18).

Silver staining was the technique employed for discerning reduced proteins because we observed diminished binding of antibody to reduced viral proteins (Fig. 1). Viral proteins of 140 and $100 \mathrm{kd}$, consistently present under non-reducing conditions, were seen as 95 and $65 \mathrm{kd}$ proteins under reducing 

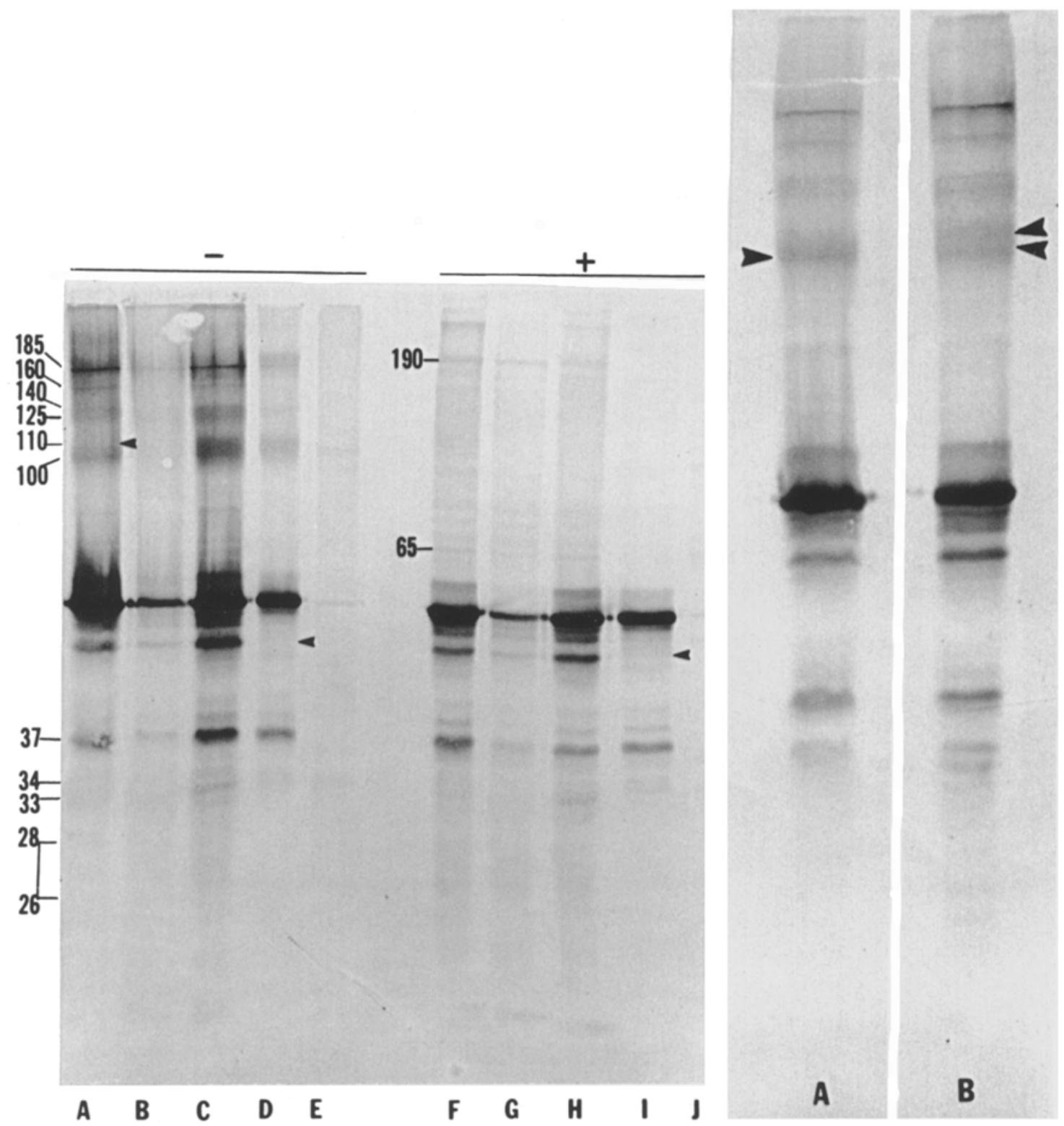

Fig. 1

Fig. 2

Fig. 1. Structural proteins of BCV-L 9 propagated in HRT-18 clones D2, 3E3, 3F3, and 4B3 as detected by Western blotting, $10 \%$ acrylamide gel. $A-E$ Non-reduced virus. $F-J$ Reduced virus. $A$ and $F$ BCV (D2), $B$ and $G$ BCV (3E3), $C$ and $H$ BCV (3F3), $D$ and $I$ BCV (4B3), $E$ and $J$ uninfected HRT-18 cells. Missing bands

Fig. 2. Structural proteins of BCV-L 9 propagated in HRT-18 clones D 2 and $3 F 3$ as detected by Western blotting. Non-reduced, $10 \%$ acrylamide gel. $A$ BCV (D2), $B$ BCV (3F3). - Differences in the profiles 


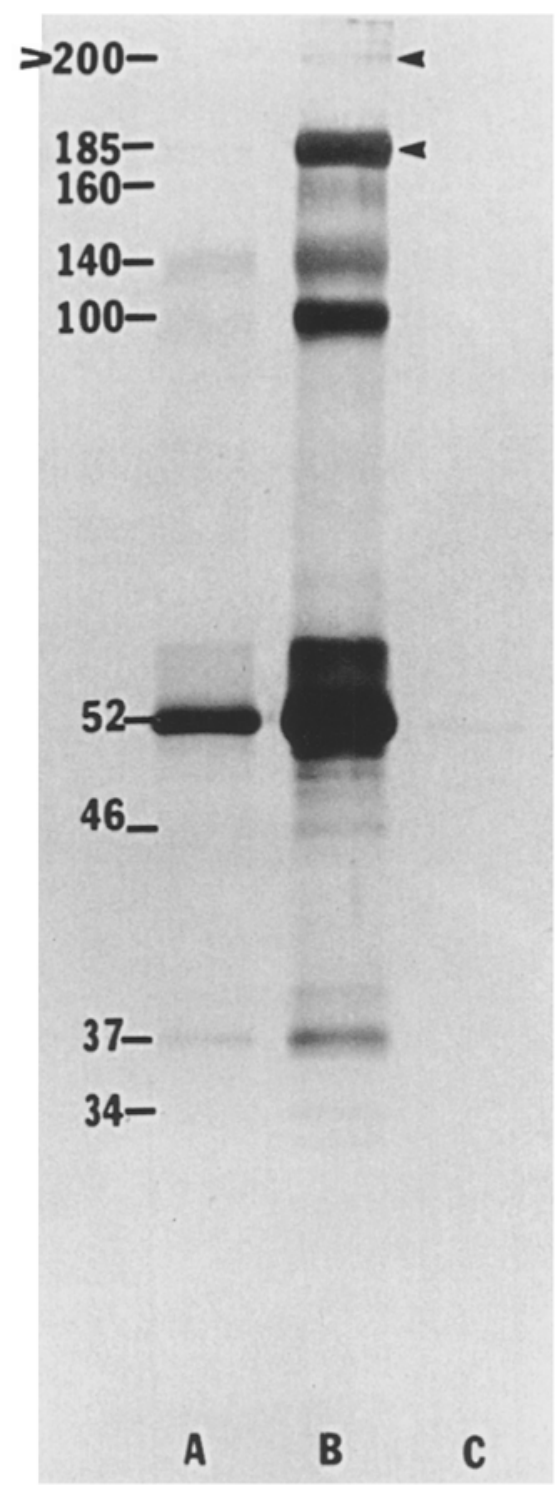

Fig. 3. Polypeptide profiles of BCV-L9 propagated in D2BFS cells and HRT-18 cells as detected by Western blotting. Non-reduced. $10 \%$ acrylamide gel. $A$ BCV (HRT-18), $B$ BCV (D2BFS), $C$ uninfected D2BFS cells. Differences in the profiles

conditions. Three distinct bands of 23,20 , and $18 \mathrm{kd}$ were converted to a cluster of bands ranging from $20-23 \mathrm{kd}$ following reduction (Fig. 4). We confidently identified reduced proteins of 190 and $65 \mathrm{kd}$ by Western blot (Fig. 1).

\section{Effect of trypsin treatment on $B C V-L 9$ polypeptides}

Purified, HRT-18-cell-propagated BCV was treated in vitro with trypsin. The profiles of untreated and trypsin-treated BCV were examined under 

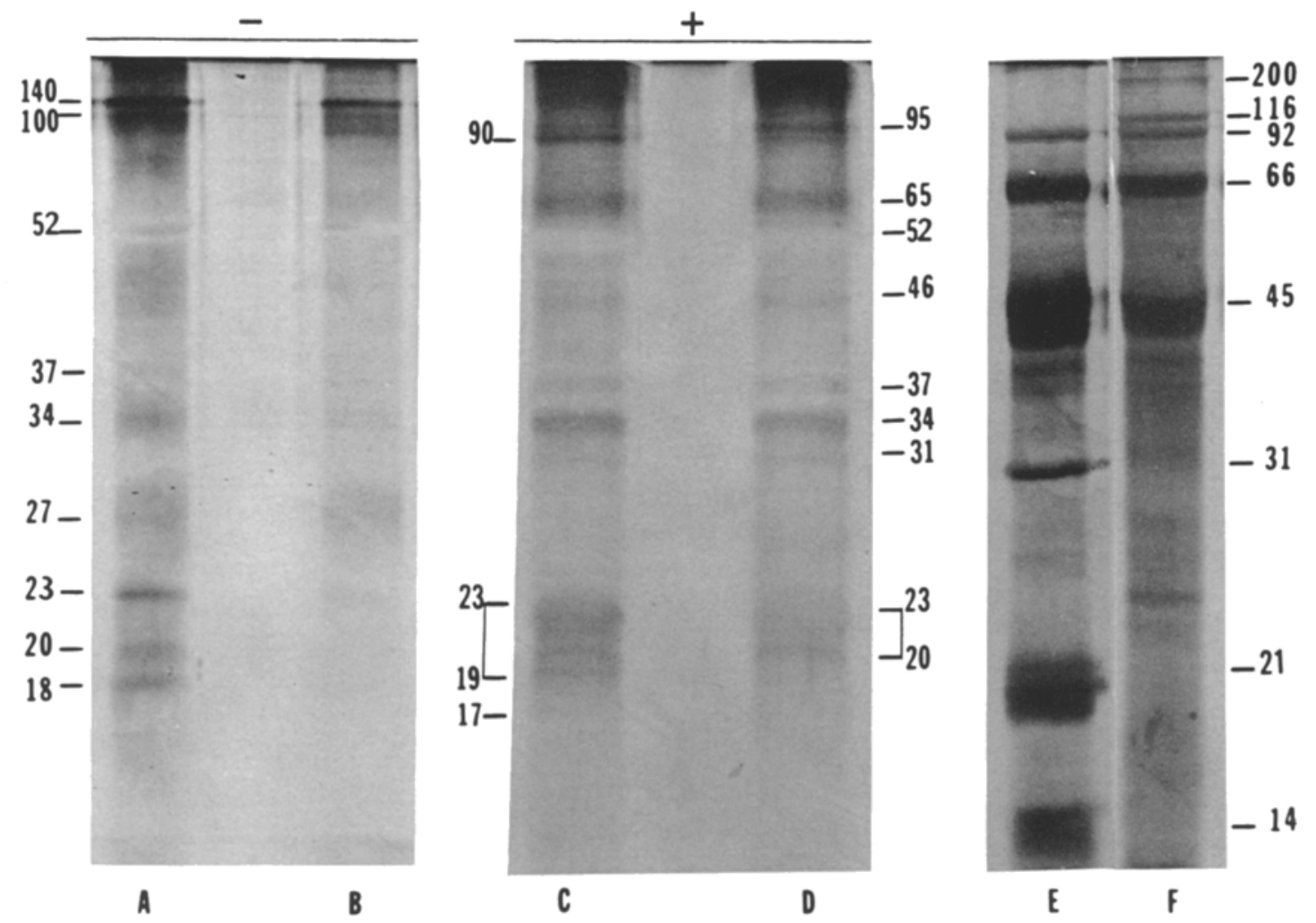

Fig. 4. Polypeptide profiles of in vitro trypsin-treated and untreated BCV-L 9 propagated in HRT-18 cells as detected by silver staining. $12 \%$ acrylamide gel. $A$ and $B$ Non-reduced virus. $C$ and $D$ Virus prepared with reducing agent. $A$ and $C$ Trypsin-treated virus, $B$ and $D$ untreated virus, $E$ and $F$ molecular weight standards

non-reducing and reducing conditions (Fig. 4). In the absence of reducing agent, the profiles were identical. Detectable bands had molecular weights of $140,100,52,27,23,20$, and $18 \mathrm{kd}$. Differences in the electrophoretic migration of trypsin-treated and untreated viral proteins were evident only under reducing conditions. A $95 \mathrm{kd}$ protein was found in non-trypsinized virions, while a $90 \mathrm{kd}$ protein was found in trypsin-treated virions. Additionally, a cluster of $20-23 \mathrm{kd}$ proteins was found in untreated virions, but this cluster changed in trypsin-treated virions to $19-23 \mathrm{kd}$ with the emergence of an additional $17 \mathrm{kd}$ protein.

BCV-L 9, propagated in D2BFS cells in the presence and absence of trypsin, was analyzed under non-reducing conditions by Western blotting (Fig. 5). Virus propagated without trypsin had the following profile: $>200$, $185,140,100,52,46,37$, and a $31-34$ kd cluster. In the presence of trypsin, the $185 \mathrm{kd}$ protein was significantly diminished in concentration with a concommitant increase of the $100 \mathrm{kd}$ protein. An additional difference between the profiles was the absence of the $31-34 \mathrm{kd}$ cluster in trypsin-treated virus. 


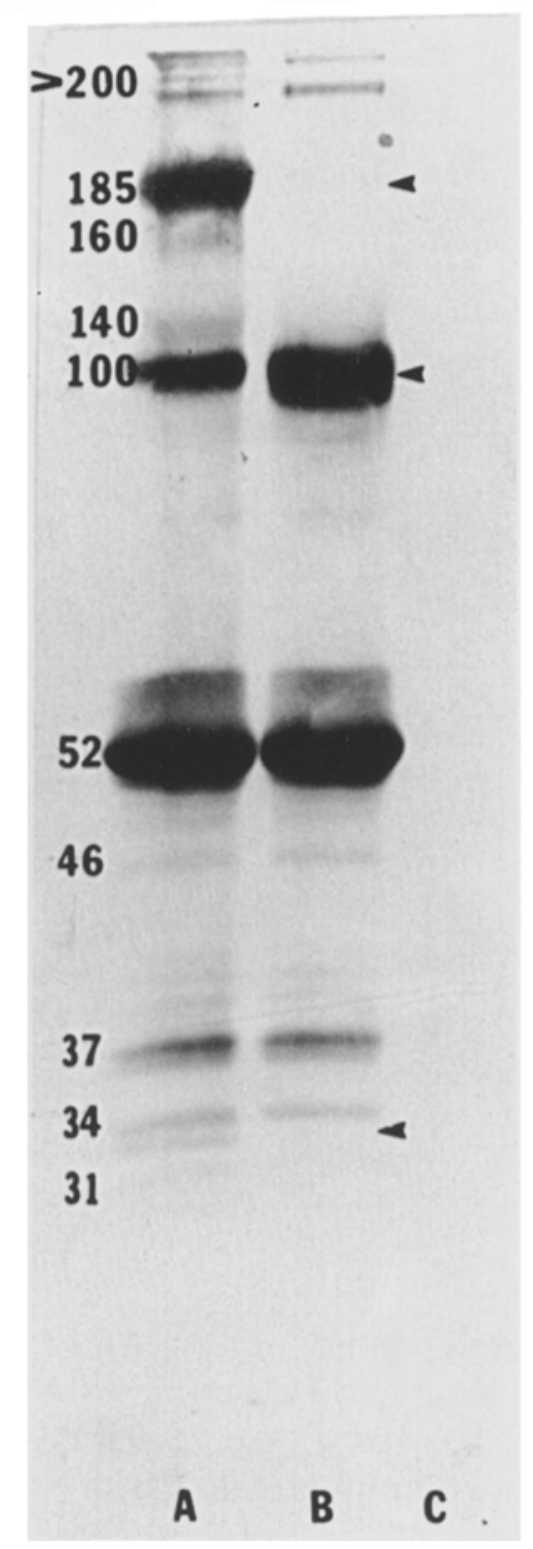

Fig. 5. Polypeptide profiles of BCV-L9 propagated in D2BFS cells in the presence and absence of trypsin as detected by Western blotting. Non-reduced. $10 \%$ acrylamide gel. $A$ Without trypsin, $B$ with trypsin, $C$ uninfected D2BFS cells. Profile differences

\section{Discussion}

We identified host cell-dependent differences in the polypeptide profile of BCVL9. Notably, the $185 \mathrm{kd}$ protein was present in high concentration in virus propagated in D2BFS cells, but it was present in low concentration in virus obtained from HRT-18 parent cells and clones. These findings are in agreement with those of Deregt et al. [5] who reported that gp 190 was present in low concentration in the Quebec BCV isolate propagated in Madin-Darby bovine 
kidney cells. A $100-110 \mathrm{kd}$ doublet band was detected in BCV propagated in clones $3 F 3,3 E 3$, and $4 \mathrm{~B} 3$, but only the $100 \mathrm{kd}$ species was evident in $\mathrm{BCV}$ from clone $\mathrm{D} 2$. This difference may reflect a variation in processing or in glycosylation of the protein. Other investigators reported that HRT-18-propagated BCV (Mebus strain) contains predominantly 120 and $100 \mathrm{kd}$ proteins which are cleaved forms of $g p 190[8,12]$. Our demonstration of a doublet band of 100 $110 \mathrm{kd}$ concurs with the results of Deregt et al. [5]. These scientists reported that cleavage of gp 190 yields two comigrating gp 100 species. Glycoprotein staining of these blots using concanavalin $\mathrm{A}$ and peroxidase [4] indicated that the $100 \mathrm{kd}$ protein was glycosylated. A $46 \mathrm{kd}$ protein reacting with antibody was evident in virus raised in all cell lines except clone 4B3 and D2BFS. It was not detected in Western blots of uninfected cells.

Silver-stained gels revealed that the 140 and $100 \mathrm{kd}$ proteins, present under non-reducing conditions, disappeared under reducing conditions. At the same time, proteins of $95 \mathrm{kd}$ and $65 \mathrm{kd}$ appeared in the presence of a reducing agent. Similar findings were reported by Deregt et al. [5]. Hogue and coworkers [7] found that the $140 \mathrm{kd}$ species consists of disulfide-linked subunits of $65 \mathrm{kd}$, but they did not observe a change in the electrophoretic migration of the $100 \mathrm{kd}$ species under reducing conditions. The 18,20 , and $23 \mathrm{kd}$ group of proteins was converted to a $20-23 \mathrm{kd}$ cluster by reduction. Western blotting also revealed a change in the electrophoretic mobility of the $185 \mathrm{kd}$ to a $190 \mathrm{kd}$ protein under reducing conditions. Rather than consisting of disulfide-linked subunits, the 185 and $100 \mathrm{kd}$ molecules and the $18-23 \mathrm{kd}$ group of proteins possibly contain intrachain disulfide bonding. Reduction could alter the migration pattern of the proteins by breaking the intrachain bonds under this assumption.

Silver staining was a superior method to Western blotting for the detection of reduced viral proteins. Due to a change in antibody binding affinity of reduced proteins, an extended reaction time in the substrate was required to visualize reduced proteins. This condition led to a high background, making it difficult to discern the viral protein bands.

The native form of the $\mathrm{BCV}$ is the disease-causing agent in natural infections of calves. Consequently, it was considered more important to focus on the nonreduced profile of $\mathrm{BCV}$. The use of antiserum obtained from a $\mathrm{BCV}$-infected calf in Western blot identified the antigenically active components of the virus.

We observed differences in the number of detectable viral proteins and their relative migration patterns between preparations that were silver stained or Western blotted. These differences emphasize the relevance of the techniques chosen for detection of viral proteins. The use of different detection methods may explain discrepancies in the reported profiles of this virus $[5,8,12,13$, 23].

We demonstrated that trypsin has an enhancing effect on the cytopathic expression and infectivity of BCV in cultures of HRT-18 and D2BFS cells [20; St. Cyr-Coats et al., submitted]. Therefore, we examined the effect of the enzyme on the structure of this virus. Interestingly, the action of trypsin on the virus 
structure was evident by silver stain only under reducing conditions. This finding indicates that trypsin-cleaved peptides were held intact by disulfide bonds. When reduced by $\beta$-mercaptoethanol, cleavage products were separable. Trypsin-dependent bands of $90 \mathrm{kd}$ and $17 \mathrm{kd}$ were detected in HRT-18 cell-propagated virus and the $20-23 \mathrm{kd}$ cluster found in untreated virions was converted to a $19-23 \mathrm{kd}$ cluster by trypsin.

We examined the polypeptide structure of BCV-L 9 propagated in D2BFS cells with and without trypsin because these infected cells fuse only in the presence of trypsin [20]. This system provided a potential model for determining the viral protein(s) responsible for cell fusion. We found that the $185 \mathrm{kd}$ protein was present in high concentration in the absence of trypsin, but only a faint band was present in virus produced with trypsin. Concommitantly, the concentration of the $100 \mathrm{kd}$ species was much higher in the presence of trypsin. These results agree with those reported by Deregt et al. [5] who demonstrated that $\mathrm{gp} 100$ is a proteolytic cleavage product of $\mathrm{gp} 190$. We conclude that cleavage of the $185 \mathrm{kd}$ protein to the $100 \mathrm{kd}$ form is required for activation of cell fusion. Trypsin was required to cleave this protein in D2BFS cells, but our data indicate that cellular enzymes cleave the $185 \mathrm{kd}$ species in HRT-18 parent cells and the four HRT-18 clones. This finding is analogous to those reported by Frana et al. [6] who found that cleavage of the $180 \mathrm{kd}$ protein of MHV-A 59 by a cellular protease or by trypsin activates the fusing capacity of that virus.

\section{Acknowledgements}

We wish to thank Mamie Burrell for her excellent technical assistance and Robin Deville for her skillful typing of this manuscript. This project was supported by Special Research Grants No. 80-CRSR-0650 and No. 86-CRSR-2-2871 from the United States Department of Agriculture, Science and Education, Washington, D.C. This paper contains parts of a dissertation presented by the senior author to the graduate School of Louisiana State University in partial fulfillment of the requirements for the degree of Doctor of Philosophy.

\section{References}

1. Burnette WN (1981) “Western blotting": electrophoretic transfer of proteins from SDSpolyacrylamide gels to unmodified nitrocellulose and radiographic detection with antibody and radioiodinated protein A. Anal Biochem 112: 195-203

2. Chanock RM, McIntosh K (1985) Parainfluenza viruses. In: Fields BN (ed) Fields virology. Raven Press, New York, pp 1241-1253

3. Choppin PW, Scheid A (1980) The role of viral glycoproteins in adsorption, penetration, and pathogenicity of viruses. Rev Infect Dis 2: 40-61

4. Clegg JCS (1982) Glycoprotein detection in nitrocellulose transfer of electrophoretically separated protein mixtures using concanavalin $\mathrm{A}$ and peroxidase: application to arenavirus and flavivirus proteins. Anal Biochem 127: 389-394

5. Deregt D, Sabara M, Babiuk LA (1987) Structural proteins of bovine coronavirus and their intracellular processing. J Gen Virol 68: 2863-2877

6. Frana MF, Behnke JN, Sturman LS, Holmes KV (1985) Proteolytic cleavage of the E2 glycoprotein of murine coronavirus: host-dependent differences in proteolytic cleavage and cell fusion. J Virol 56: 912-920 
7. Garten W, Bosch FX, Linder D, Rott R, Klenk HD (1981) Proteolytic activation of the influenza virus hemagglutinin: the structure of the cleavage site and enzymes involved in cleavage. Virology 115: 361-374

8. Hogue BG, King B, Brian DA (1984) Antigenic relationships among proteins of bovine coronavirus, human respiratory coronavirus $\mathrm{OC} 43$, and mouse hepatitis coronavirus A59. J Virol 51: 384-388

9. Homma M (1971) Trypsin action on the growth of Sendai virus in tissue culture cells. I. Restoration of the infectivity for $\mathrm{L}$ cells by direct action of trypsin on $\mathrm{L}$ cell-borne Sendai virus. J Virol 8: 619-629

10. Homma M (1972) Trypsin action on the growth of Sendai virus in tissue culture cells. II. Restoration of the hemolytic activity of L cell-borne Sendai virus by trypsin. J Virol 9: $829-835$

11. Homma M, Tamagawa S (1973) Restoration of the fusion activity of L cell-borne Sendai virus by trypsin. J Gen Virol 19: 423-426

12. King B, Brian DA (1982) Bovine coronavirus structural proteins. J Virol 42: 700-707

13. King B, Potts BJ, Brian DA (1985) Bovine coronavirus hemagglutinin protein. Virus Res 2: $53-59$

14. Laemmli UK (1970) Cleavage of structural proteins during the assembly of bacteriophage T4. Nature 227: 680-685

15. Mebus CA, Stair EL, Rhodes MB, Twiehaus MJ (1973) Neonatal calf diarrhea: propagation, attenuation, and characteristics of a coronavirus-like agent. Am $J$ Vet Res 34: $145-150$

16. Merril CR, Goldmann D, Sedman SA, Ebert MH (1981) Ultrasensitive stain for proteins in polycrylamide gels shows regional variation in cerebrospinal fluid proteins. Science 211: $1437-1438$

17. Muilerman HG, Ter Hart HGJ, Van Dijk W (1982) Specific detection of inactive enzyme protein after polyacrylamide gel electrophoresis by a new enzyme-immunoassay method using unspecific antiserum and partially purified active enzyme: application to rat liver phosphodiesterase I. Anal Biochem 120: 46-51

18. Murphy BR, Webster RG (1985) Influenza viruses. In: Fields BN (ed) Fields virology. Raven Press, New York, pp 1179-1240

19. Nagai Y, Klenk HD, Rott R (1976) Proteolytic cleavage of the viral glycoproteins and its significance for the virulence of Newcastle disease virus. Virology 72: 494-508

20. St. Cyr-Coats K, Storz J (1988) Bovine coronavirus-induced cytopathic expression and plaque formation: host cell and virus strain determine trypsin dependence. J Vet Med 35: $48-56$

21. Storz J, Rott R, Kaluza G (1981) Enhancement of plaque formation and cell fusion of an enteropathogenic coronavirus by trypsin treatment. Infect Immun 31: 1214-1222

22. Wege H, Wege H, Nagashima K, ter Meulen V (1979) Structural polypeptides of murine coronavirus JHM. J Gen Virol 42: 37-47

23. Williams JR (1983) Proteolytic alteration of bovine coronavirus biological and physical properties. PhD Dissertation. Colorado State University, Fort Collins, Colorado, U.S.A.

Authors' address: K. St. Cyr-Coats, Department of Veterinary Microbiology and Parasitology, School of Veterinary Medicine, Louisiana State University, Baton Rouge, LA 70803, U.S.A. 